\title{
Influence of Application Methods of Bio- Fertilization on Vegetative Growth, Seed Yield and Chemical Composition of Fenugreek Plants
}

\author{
F. M. A. Matter and A. I. B. Abou-Sreea \\ Department of Horticulture Faculty of Agriculture, Fayoum \\ University, Egypt.
}

\begin{abstract}
7 HE FIELD work was carried out at the experimental farm "Demo" in faculty of Agriculture, Fayoum University, during two successive seasons of 2013/2014 and 2014/2015. The aim was to investigate the effect of foliar, ground application (soil drenching) and both the two methods using $(0,5,10$ and $15 \mathrm{~g} / \mathrm{l})$ of bio-fertilization with yeast (Saccharomyces cerevisiae) on the growth, yield and chemical constituents of Fenugreek plants. The results assured that Fenugreek plants highly reacted positively and significantly to different methods of bio-fertilization with active dry yeast either by spraying or soil drenching or using both together. Using the highest concentrations (10 and $15 \mathrm{~g} / \mathrm{l})$ of yeast by spraying or soil drenching, as individually, or applying them together as interaction proved to have the leadership in enhancing and increasing all vegetative growth characters, plant height, branches number plant ${ }^{-1}$, fresh and dry weight plant $^{-1}$, seed yield and its contents of mucilage (\%), trigonelline, protein and chemical composition of Fenugreek plants, chlorophyll a, b, carotenoids' contents and total carbohydrates content.
\end{abstract}

Fenugreek plants should be sprayed and drenched at a concentration of 10 and $15 \mathrm{~g} / \mathrm{l}$ of yeast. Moreover, active dry yeast should be more mechanized and used in agriculture as a harmless biofertilizer with a marvellous ability in increasing seed yield and chemical constituents.

Keywords: Bio-fertilization, Fenugreek (Trigonella foenum-graecum L.), Active dry yeast (Saccharomyces cerevisiae), Mucilage and Trigonelline.

Fenugreek (Trigonella foenum-graecum) belongs to family (Fabaceae) that grows annually, and is widely cultivated in the Mediterranean countries and Asia. The dried seeds have been traditionally used in Egypt, India, China and in some parts of the Europe for their beneficial health effects such as galactogouge, antibacterial, anti-inflammatory, insulinotropic, and rejuvenating properties (Im and Maliakel 2008). Pleasantly bitter and slightly sweet fenugreek seeds, which are available in whole and ground forms, are used as a source of flavoring for foods including curry powders, spice blends and teas. The seeds have horny and relatively large layer of white and semi-transparent endosperm encircling central hard, yellow 
embryo (Betty 2008). Wonderful functional and medicinal values of fenugreek are attributed to its chemical composition (20-25\% protein, $45-50 \%$ dietary fiber, 20 $25 \%$ mucilaginous soluble fiber, 6-8\% fixed fatty acids and essential oils, and 2$5 \%$ steroidal saponins. Moreover, some minor components such as alkaloids (trigonolline, cholin, gentianine, carpaine, etc.), free unnatural amino acids (4hydroxyisoleucine), and individual spirostanols and furastanols like diosgenin, gitogenin and yamogenin have also been identified and determined as the main components for its various biological effects (Trivedi et al., 2007 ).

Bio fertilization of horticulture crops had drawn the attention of research workers and had become in the last decades a positive alternative to chemical fertilizers. Bio fertilizers are reasonably safer to the environment compared to chemical fertilizers. It is very important for medicinal and aromatic plants to produce the best product in both quantity and quality.

Active dry yeast (ADY), a natural biofertilizer, is safety and causes various promoted effects on plants and is a natural source of cytokinins which simulates cell division and enlargement as well as the synthesis of protein, nucleic acid and B-vitamin (Ezz El-Din and Hendawy, 2010). Aactive dry yeast releases $\mathrm{Co}_{2}$ which reflected in improving net photosynthesis (Kurtzman and Fell, 2005). In addition, Yeast is a natural source of most nutritional elements ( $\mathrm{Na}, \mathrm{Ca}, \mathrm{Fe}, \mathrm{K}, \mathrm{P}$, S, Zn and Si) (Nagodawithana, 1991). Active dry yeast contains dry matter of $9.3 \%$, protein $47.2 \%$, arginine $2.6 \%$, glycine $2.6 \%$, histidine $1.4 \%$ isolaysine $2.9 \%$, lauicine $3.5 \%$, hysine $3.8 \%$, methionine cystine $0.6 \%$, phenyl-alanine $3 \%$, tyrosine $2.1 \%$, threonine $2.6 \%$, tryptophan $0.5 \%$ and vitamin B $2.9 \%$ (N.R.P., 1977). Yeast as well has tryptophan which is considered a precursor of IAA, so it increases size of fruit (Warring and Phillips, 1973 and Moor, 1979). Furthermore, cytokinins are one of yeast's important components which delay the aging of leaves by the way of retardation the degradation of chlorophyll and enhancing the synthesis of proteins and RNA. In soil solution to form low solubility substances called phosphate fixation. This is dominating with high soil $\mathrm{pH}$ and greater percentage of calcium carbonate. Soil microorganisms which convert the insoluble form of phosphorus to soluble one play an important role in supplying the plants with available phosphorus (Ahmed et al., 1997).

El-Naggar et al. (2015) stated that the highest values of vegetative growth (plant height, number of branches, leaves numbers, leaf area and leaves dry weight) and total chlorophyll content were obtained by adding active dry yeast (ADY) at $6.0 \mathrm{~g} / \mathrm{L}$ on Ocimum basilicum $\mathrm{L}$.

Salman (2004), on Ocimum basilicum, found that inoculation of active dry yeast at $150 \mathrm{ml} /$ plant alone increased number of branches, fresh weight /plant and per feddan, leaf area and herb, leaves and stems dry weight /plant, total carbohydrates content and chlorophyll "a" compared with the control.

Egypt. J. Hort. Vol. 43, No.1 (2016) 
Abd El-Azim and Abd El-Gawad (2008) concluded that using combinations of yeast applied as soil drench plus foliar spraying methods gave the best yield of Thymus vulgaris, L.

This investigation aimed to study the effect of bio-fertilization with yeast (Saccharomyces cerevisiae) applied as soil drench, and/or foliar spraying methods on the vegetative growth, seed yield and chemical composition of Fenugreek (Trigonella foenum-graecum L.) plants as individual and interaction effect.

\section{Materials and Methods}

The present investigation was carried out at the experimental farm "Demo" in Faculty of Agriculture, Fayoum University, during two successive seasons 2013/2014 and 2014/2015.

Seeds of Fenugreek were obtained from Medicinal and Aromatic Plants Research Department, Hort. Res. Inst., ARC, Ministry of Agriculture, Egypt Seeds were threading on $17^{\text {th }}$ and $18^{\text {th }}$ of Oct. (for two seasons, respectively) and sown on one side of the ridge in sandy soil.

The layout of the experiment used was "factorial experimental" in complete randomized block design system with three replicates. Each replicate contained 3 plots, each plot contained four rows. The plot area was $2 \times 3 \mathrm{~m}$ and each row was $50 \mathrm{~cm}$ apart and $3 \mathrm{~m}$ in length. All the plants received the recommended agriculture practices.

Active dry yeast was applied as foliar application and soil drench at $0,5,10$ and $15 \mathrm{~g} / \mathrm{l}$. These applications were used three times /season. The first one was added after 50 days from sowing, followed by the second and the third ones after 3 and 6 weeks from the first one, respectively. Later the solution was previously prepared by dissolving the active dry yeast from the above mentioned treatments in $2 \%$ of sugar solution (known weight $20 \mathrm{~g}$ sugar in $1 \mathrm{~L}$ of water), then leaving them for 7-8 hours allowing the yeast to propagate, then the volume was completed with water according to the concentration used.

The mechanical and chemical analysis of soil Table 1 used was carried out according to Klute (1986) and Page et al. (1982).

\section{Data recorded}

Vegetative growth

At the age of 160 days (during vegetative stage), the outer two rows ( $1^{\text {st }}$ and $4^{\text {th }}$ ) of each plot were chosen from each experimental unit and cut off at ground level and submitted to the following determinations:

Plant height $(\mathrm{cm})$, number of branches plant ${ }^{-1}$, fresh and dry weights plant ${ }^{-1}$ $(\mathrm{g})$, root weight plant $^{-1}(\mathrm{~g})$, root length $(\mathrm{cm})$ plant $^{-1}$ 
Yield characters and chemical constituents of fenugreek seeds

At full maturity fruit stage (190 days), the central ridges were chosen from each experimental unit, to estimate the following yield characters:

Number of pods plant ${ }^{-1}$, seed yield plant ${ }^{-1}(\mathrm{~g})$, seed yield feddan ${ }^{-1}(\mathrm{~kg})$, mucilage content $(\%)$ in seeds powdered dry matter according to (Sabale et al., 2009), content of seed trigonelline (mg.g $\mathrm{g}^{-1} \mathrm{DW}$ ) according to (Zheng and Ashihara 2004) and seed protein content (g. $\mathrm{g}^{-1} \mathrm{DW}$ ) according to (Jani et al., 2009)

TABLE 1. Some mechanical and chemical analysis of used soil samples obtained from the experimental locations of Demo.

\begin{tabular}{|c|c|c|c|c|c|c|c|c|c|c|}
\hline \multirow{2}{*}{ Years } & \multicolumn{10}{|c|}{ Mechanical analysis } \\
\hline & \multicolumn{3}{|c|}{ Sand \% } & Silt \% & \multicolumn{3}{|c|}{ Clay \% } & \multicolumn{3}{|c|}{ Texture class } \\
\hline $2013 / 2014$ & \multicolumn{3}{|c|}{78.29} & 14.93 & \multicolumn{3}{|c|}{9.81} & \multicolumn{3}{|c|}{ Sandy loam } \\
\hline $2014 / 2015$ & \multicolumn{2}{|c|}{77.97} & \multicolumn{2}{|c|}{15.95} & \multicolumn{3}{|c|}{8.68} & \multicolumn{3}{|c|}{ Sandy loam } \\
\hline \multirow{2}{*}{ Years } & \multicolumn{10}{|c|}{ Available nutrients (mg/kg) } \\
\hline & $\begin{array}{l}\text { Soil } \\
\text { pH }\end{array}$ & ECe & $\mathbf{N}$ & $\mathbf{P}$ & $\mathbf{K}$ & $\mathbf{F e}$ & Mn & $\mathbf{Z n}$ & Mg & $\begin{array}{c}\mathrm{CaCo}_{3} \\
\%\end{array}$ \\
\hline $2013 / 2014$ & 7.81 & 3.71 & 17.53 & 9.77 & 1.67 & 2.27 & 4.83 & 0.33 & 8.77 & 10.31 \\
\hline $2014 / 2015$ & 7.83 & 3.73 & 18.67 & 8.81 & 1.60 & 2.25 & 5.91 & 0.35 & 8.71 & 9.91 \\
\hline
\end{tabular}

Chemical analysis of fenugreek plants

Fresh leaves at the age of 160 days, chlorophyll a, b and carotenoids contents were determined according to (Arnon 1949) and total carbohydrates content (\%) in powdered dry matter of herb determined color-metrically according to (Herbert et al. 1971).

\section{Statistical analysis}

Results were statistically analysis using the LSD at probability level of 5\% for comparison (Gomez and Gomez 1983).

\section{Results and Discussion}

Vegetative growth characters

Effect of bio-fertilization with yeast applied as foliar application spraying

Data presented in Table 2 show that spraying Fenugreek plants with active dry yeast caused a gradual significant increase in plant height, number of branches plant ${ }^{-1}$, fresh and dry weights plant ${ }^{-1}$, leaf area plant ${ }^{-1}$ and leaves number plant $^{-1}$ namely, the more concentration increased the values of these parameters

Egypt. J. Hort. Vol. 43, No.1 (2016) 
were obtained. Treating the plants with $15 \mathrm{~g} / \mathrm{l}$ concentration was the most effective treatment in this respect as it gave the highest results in both seasons. The approximate increase mean in plant height, the number of branches plant ${ }^{-1}$, fresh and dry weights plant ${ }^{-1}$, leaf area plant $^{-1}$ and leaves number plant ${ }^{-1}$ for this treatment in comparison with control was $37,26,26,44.5,71$ and $43.5 \%$ in both seasons, respectively.

Differences between values of all vegetative growth characters treatments are significant in both seasons except for branches number which was insignificant in the first and second season.

The elongation and improving of plant height, increase in the number of leaves and increment of leaf area may be due to the role of (ADY) fertilizers by enhancing the cell division rate and cell enlargement (Shalaby and El- Nady, 2008 and Khedr \& Farid, 2000) as yeast contains cytokinins that improving the accumulation of soluble metabolites (Muller and Leopold 1966) and also stimulate cell proliferation and differentiation, controlling shoot and root morphogenesis and chloroplast maturation (Amer, 2004). In addition, these results may be also due to the physiological roles of vitamins and amino acids in the yeast extract, as stated by Armanious, (1987), which increased the metabolic processes role and levels of indogenous hormones, i.e., IAA and $\mathrm{GA}_{3}$ (Chaliakhyan, 1957). Moreover, the fermentation process that occurred in the presence of dry yeast produces $\mathrm{Co}_{2}$ in high quantity, a factor that may increase photosynthesis and consequently plant growth, the high content of dry yeast from vit. $\mathrm{B}_{5}$ and minerals might play a considerable role in orientation and translocation of metabolites from leaves into the productive organs (Mohamed et al., 1999).

These results are in agreement with (Jacoub, 1999) on Ocimum basilicum and Thymus vulgaris, (Naga, 2004) on Fennel plants, (Abou-Dahab et al., 2009) on Lovage plants, (Moghadam et al., 2012) on Lilium Asiatic, (Khaled et al., 2014) on Majoram plant, (Alves et al., 2005) on Coriandrum sativum, (Carmen et al., 2006) on Ocimum basilicum, (Heikal, 2005) on Thymus vulgaris and (Mady, 2009) on Marjoram and Sage.

Effect of bio-fertilization with yeast applied as soil drench

Shown results in Table 2 state that using high concentrations of yeast (10 and $15 \mathrm{~g} / \mathrm{l})$ gave a remarkable increase in all vegetative growth characters i.e., plant height, number of branches plant ${ }^{-1}$, fresh and dry weight plant $^{-1}$, leaf area plant ${ }^{-1}$ $\left(\mathrm{cm}^{2}\right)$ and leaves number plant ${ }^{-1}$, in both seasons with significant differences between values except for results of dry weight plant $^{-1}$ which reveal a little bit insignificant differences. The obtained values of this treatment in all parameters increase than the control with $18.5,49.5,33.5,10.5,33$ and $21 \%$ as a mean in both seasons, respectively.

The given results are close to those declared by (Salman 2004) on Ocimum basilicum. 
Effect of the interaction between application spraying and soil drench

As indicated in Table 2, spraying the plants and drenching the soil using the highest concentrations $(15 \mathrm{~g} / \mathrm{L})$ for both treatments has the big share in achieving the optimum significant values concerning fresh and dry weight plant $^{-1}$, leaves number plant ${ }^{-1}$ and also the highest but insignificant records for leaf area plant ${ }^{-1}$ in both seasons. While, spraying with $15 \mathrm{~g} / \mathrm{L}$ plus soil drenching at $10 \mathrm{~g} / \mathrm{L}$ led significantly to obtain the highest plant height plant ${ }^{-1}$ and branches number plant ${ }^{-1}$ in both seasons.

The approximate increase mean in plant height, number of branches plant ${ }^{-1}$ fresh and dry weight plant ${ }^{-1}$, leaf area plant ${ }^{-1}$ and leaves number plant ${ }^{-1}$ for this treatments were $64,135.5,143.5,146.5,128.5$ and $122.5 \%$ as a mean in both seasons, respectively than the control. These results are correspondent to those obtained by (Ahmed 2002) on Leucaena leucocephala.

Yield characters and chemical constituents of fenugreek seeds Effect of bio-fertilization with yeast applied as foliar application spraying

Table 3 also, reveals that the use of the highest concentration of active dry yeast $(15 \mathrm{~g} / \mathrm{l})$ recorded significantly the highest values of pods number plant $^{-1}$, seed weight plant ${ }^{-1}$, seed yield feddan ${ }^{-1}$ and seed content of mucilage, trigonelline and protein, in both seasons. Such a treatment gave an increase the means of seed yield $79 \%$ in both seasons, respectively compared to the control.

In this concern Haridi (1987) working on Salvia officinalis concluded that the positive effect of active dry yeast may be attributed to its components as cytokinine and vit-B which are active in improving the growth and productivity.

These results are in line with those obtained by Ahmed et al. (1998) on Hibiscus sabdariffa and Ahmed et al. (2001) on Ambrosia maritime.

\section{Effect of bio-fertilization with yeast applied as soil drench}

It is clarified from Table 3 that drenching with the highest concentration of active dry yeast $(10$ and $15 \mathrm{~g} / \mathrm{l})$, resulted significantly in attaining the highest records of pods number plant ${ }^{-1}$, seeds weight plant $^{-1}(\mathrm{~g})$, seeds yield feddan ${ }^{-1}(\mathrm{~kg})$ and seeds mucilage (\%) trigonelline and protein content in both seasons. The increase of seed yield occurred by applying this treatment was $58.5 \%$ than the control in both seasons.

Effect of the interaction between application spraying and soil drench

The interaction between spraying at $15 \mathrm{~g} / \mathrm{l}$ and soil drenching at $10 \mathrm{~g} / \mathrm{L}$ of active dry yeast was the best treatment for obtaining the highest records of seeds weight plant $^{-1}$ and seeds yield feddan ${ }^{-1}$, as revealed in Table 3. Such a treatment gave an increase of $111.5 \%$ in both seasons, respectively compared to the control treatment. As well as, the highest concentration of yeast $(15 \mathrm{~g} / \mathrm{L})$ together either in spraying or in drenching resulted in giving the highest significant results regarding pods number plant ${ }^{-1}$ and seeds mucilage $(\%)$, trigonelline and protein content in both seasons. These given results are in harmony with those found by (Abd ElAzim and Abd El-Gawad 2008) on Thymus vulgaris.

Egypt. J. Hort. Vol. 43, No.1 (2016) 
TABLE 2. Effect of bio-fertilization with yeast applied as foliar application spraying, soil drench methods and their interaction on the vegetative growth characters of fenugreek plants.

\begin{tabular}{|c|c|c|c|c|c|c|c|c|c|c|}
\hline \multirow{3}{*}{$\underbrace{\text { Spraying(a) }}_{\text {Drenching(b) }}$} & \multicolumn{5}{|c|}{$1^{\text {st }}$ season (2013|2014) } & \multicolumn{5}{|c|}{$2^{\text {nd }}$ season (2014/2015) } \\
\hline & \multicolumn{10}{|c|}{ Plant height plant ${ }^{-1}(\mathrm{~cm})$} \\
\hline & $\mathbf{0} \mathrm{g} / \mathrm{L}$ & $5 \mathrm{~g} / \mathrm{L}$ & $10 \mathrm{~g} / \mathrm{L}$ & $15 \mathrm{~g} / \mathrm{L}$ & L $\mid$ Mean & $\begin{array}{ll}n & 0 \mathrm{~g} / \mathrm{L}\end{array}$ & $5 \mathrm{~g} / \mathrm{L}$ & $10 \mathrm{~g} / \mathrm{L}$ & $15 \mathrm{~g} / \mathrm{L}$ & Mean \\
\hline $0 \mathrm{~g} / \mathrm{L}$ & 27.10 & 31.78 & 41.48 & 34.16 & 33.63 & 30.26 & 34.93 & 35.12 & 32.16 & 33.12 \\
\hline $5 \mathrm{~g} / \mathrm{L}$ & 29.41 & 35.34 & 40.33 & 45.45 & 37.63 & 26.66 & 39.15 & 37.15 & 44.46 & 36.86 \\
\hline $10 \mathrm{~g} / \mathrm{L}$ & 31.28 & 38.82 & 36.33 & 46.65 & 38.27 & 34.26 & 40.96 & 35.72 & 47.23 & 39.54 \\
\hline $15 \mathrm{~g} / \mathrm{L}$ & 32.16 & 31.60 & 44.77 & 40.41 & 37.24 & 33.91 & 33.88 & 43.38 & 45.42 & 39.15 \\
\hline Mean & 29.99 & 34.39 & \begin{tabular}{|l|l|}
40.73 \\
\end{tabular} & \begin{tabular}{|l|l|}
41.67 \\
\end{tabular} & & 31.27 & 37.23 & \begin{tabular}{|l|l}
37.84 \\
\end{tabular} & 42.32 & \\
\hline L.S.D 5\% & \multicolumn{3}{|c|}{$\begin{array}{ll}(a)=3.11 & \text { (b) }=3.11\end{array}$} & \multicolumn{2}{|c|}{$(\mathrm{axb})=6.21$} & \multicolumn{3}{|c|}{$(a)=3.41 \quad(b)=3.41$} & \multicolumn{2}{|c|}{$(\mathrm{axb})=6.81$} \\
\hline \multicolumn{11}{|c|}{ Number of branches plant ${ }^{-1}$} \\
\hline $0 \mathrm{~g} / \mathrm{L}$ & 2.33 & 5.00 & 2.00 & \begin{tabular}{|l|}
4.33 \\
\end{tabular} & \begin{tabular}{|l|}
3.42 \\
\end{tabular} & 2.69 & 4.14 & 3.08 & 4.67 & 3.65 \\
\hline $5 \mathrm{~g} / \mathrm{L}$ & 4.67 & 3.33 & 5.00 & 4.00 & 4.25 & 4.45 & 3.78 & 6.07 & 5.08 & 4.85 \\
\hline $10 \mathrm{~g} / \mathrm{L}$ & 5.33 & 4.33 & 5.00 & 5.67 & 5.08 & 5.72 & 4.72 & 5.34 & 6.12 & 5.48 \\
\hline $15 \mathrm{~g} / \mathrm{L}$ & 4.00 & 4.33 & 5.33 & 5.33 & 4.75 & 3.13 & 4.69 & 5.74 & 5.81 & 4.84 \\
\hline Mean & 4.08 & 4.25 & 4.33 & 4.83 & & 4.00 & 4.33 & 5.06 & 5.42 & \\
\hline L.S.D 5\% & \multicolumn{3}{|l|}{ (a) $=$ n.s. } & \multicolumn{2}{|c|}{$(\mathrm{axb})=1.11$} & \multicolumn{3}{|c|}{$(a)=$ n.s. $\quad(b)=0.51$} & \multicolumn{2}{|c|}{$(\mathrm{axb})=1.01$} \\
\hline \multicolumn{11}{|c|}{${\text { Fresh weight } \text { plant }^{-1}(\mathrm{~g})}$} \\
\hline $0 \mathrm{~g} / \mathrm{L}$ & 13.10 & 15.43 & 23.94 & 22.41 & \begin{tabular}{|l|}
18.72 \\
\end{tabular} & 18.83 & 18.62 & 29.94 & \begin{tabular}{|l|l|}
19.88 & \\
\end{tabular} & 21.82 \\
\hline $5 \mathrm{~g} / \mathrm{L}$ & 23.42 & 23.64 & 20.19 & 26.18 & 23.36 & 24.48 & 23.38 & \begin{tabular}{|l|}
22.07 \\
\end{tabular} & 30.41 & 25.09 \\
\hline $10 \mathrm{~g} / \mathrm{L}$ & 27.61 & 24.99 & 22.63 & 26.01 & 25.31 & 26.11 & 28.86 & \begin{tabular}{|l|}
21.22 \\
\end{tabular} & 31.24 & 26.86 \\
\hline $15 \mathrm{~g} / \mathrm{L}$ & 23.41 & 23.55 & 23.75 & 33.94 & 26.16 & 23.42 & 25.5 & 24.61 & 37.72 & 27.81 \\
\hline Mean & 21.89 & 21.90 & 22.63 & 27.14 & & 23.21 & 24.09 & \begin{tabular}{|l|}
24.46 \\
\end{tabular} & 29.81 & \\
\hline L.S.D 5\% & \multicolumn{3}{|c|}{$(a)=1.60 \quad(b)=1.60$} & \multicolumn{2}{|c|}{$(\mathrm{axb})=3.10$} & \multicolumn{2}{|c|}{$(a)=2.10$} & b) $=2.10$ & \multicolumn{2}{|c|}{$(a x b)=4.10$} \\
\hline \multicolumn{11}{|c|}{ Dry weight plant $^{-1}(\mathrm{~g})$} \\
\hline $0 \mathrm{~g} / \mathrm{L}$ & 5.03 & 9.59 & \begin{tabular}{|l|l|}
13.65 \\
\end{tabular} & \begin{tabular}{|l|l}
9.09 \\
\end{tabular} & \begin{tabular}{|c|}
9.34 \\
\end{tabular} & 6.28 & 11.96 & 13.83 & 10.02 & 10.52 \\
\hline $5 \mathrm{~g} / \mathrm{L}$ & 10.97 & 8.83 & 7.40 & 12.21 & 9.85 & 9.88 & 11.62 & \begin{tabular}{l|l|}
12.18 \\
\end{tabular} & 12.86 & 11.64 \\
\hline $10 \mathrm{~g} / \mathrm{L}$ & 6.53 & 11.25 & 10.17 & 12.62 & 10.14 & 12.79 & 11.54 & 9.17 & 13.45 & 11.74 \\
\hline $15 \mathrm{~g} / \mathrm{L}$ & 7.49 & 8.50 & 9.98 & 13.19 & 9.79 & 9.56 & 10.45 & 11.98 & \begin{tabular}{|l|}
14.51 \\
\end{tabular} & 11.63 \\
\hline Mean & 7.51 & 9.54 & 10.30 & \begin{tabular}{|l|}
11.78 \\
\end{tabular} & & 9.63 & 11.39 & \begin{tabular}{|l|}
11.79 \\
\end{tabular} & \begin{tabular}{|l|}
12.71 \\
\end{tabular} & \\
\hline L.S.D 5\% & \multicolumn{3}{|c|}{$(a)=0.80 \quad(b)=$ n.s. } & \multicolumn{2}{|c|}{$(\mathrm{axb})=1.60$} & \multicolumn{3}{|c|}{$(a)=1.70 \quad(b)=$ n.s. } & (axb) & $=3.30$ \\
\hline & & & leaf area & a plant $t^{-1}$ & $-1(\mathrm{~cm})^{2}$ & & & & & \\
\hline $0 \mathrm{~g} / \mathrm{L}$ & 3.96 & 4.5 & 4.61 & 7.36 & 5.11 & 3.35 & 4.14 & 6.77 & 6.62 & 5.22 \\
\hline $5 \mathrm{~g} / \mathrm{L}$ & 3.91 & 4.14 & 6.50 & 7.49 & 5.51 & 4.14 & 6.16 & 6.37 & 7.29 & 5.99 \\
\hline $10 \mathrm{~g} / \mathrm{L}$ & 5.36 & 6.79 & 7.61 & 7.40 & 6.79 & 4.36 & 5.64 & 5.09 & 7.06 & 5.54 \\
\hline $15 \mathrm{~g} / \mathrm{L}$ & 5.57 & 7.08 & 7.25 & 8.40 & 7.08 & 4.59 & 6.77 & 6.93 & 8.20 & 6.62 \\
\hline Mean & 4.70 & 5.63 & 6.49 & 7.66 & & 4.11 & 5.68 & 6.29 & 7.29 & \\
\hline L.S.D 5\% & (a) $=1$ & $.06 \quad(b)=$ & $=1.06$ & $(\mathrm{axb})=\mathrm{n}$ & n.s. & (a) $=1$. & $.04 \quad(1$ & b) $=1.04$ & $4 \quad(\mathrm{axb}$ & )$=n \cdot s$. \\
\hline & & & eaves nt & umber & plant $^{-1}$ & & & & & \\
\hline $0 \mathrm{~g} / \mathrm{L}$ & 42.41 & 52.11 & \begin{tabular}{|l|}
54.16 \\
\end{tabular} & \begin{tabular}{|l|}
65.87 \\
\end{tabular} & \begin{tabular}{|l|}
53.64 \\
\end{tabular} & 38.74 & 46.96 & 52.47 & 63.92 & 50.52 \\
\hline $5 \mathrm{~g} / \mathrm{L}$ & 43.25 & 53.46 & \begin{tabular}{|l|}
53.22 \\
\end{tabular} & \begin{tabular}{|l|}
64.16 \\
\end{tabular} & \begin{tabular}{|l|}
53.52 \\
\end{tabular} & 48.08 & 51.90 & \begin{tabular}{|l|}
47.92 \\
\end{tabular} & 67.30 & 53.80 \\
\hline $10 \mathrm{~g} / \mathrm{L}$ & 51.24 & 57.95 & 62.81 & 63.81 & 58.95 & 46.29 & 57.20 & 57.84 & 63.52 & 56.21 \\
\hline $15 \mathrm{~g} / \mathrm{L}$ & 47.19 & 55.49 & \begin{tabular}{|l|}
57.57 \\
\end{tabular} & 85.14 & 61.35 & 45.87 & 57.7 & \begin{tabular}{l|l|}
59.76 \\
\end{tabular} & 94.95 & 64.57 \\
\hline Mean & 46.02 & 54.75 & \begin{tabular}{|l|}
56.94 \\
\end{tabular} & \begin{tabular}{|l|l|}
69.75 \\
\end{tabular} & & 44.75 & \begin{tabular}{|l|}
53.44 \\
\end{tabular} & \begin{tabular}{|l|l|}
54.50 \\
\end{tabular} & 72.42 & \\
\hline L.S.D 5\% & $(a)=3.31$ & $0 \quad(b)=$ & $=3.30$ & $(a x b)=$ & $=6.50$ & (a) $=4$. & $1.60 \quad(\mathrm{~b}$ & $=4.60$ & $(a x b)=$ & $=9.30$ \\
\hline
\end{tabular}

Egypt. J. Hort. Vol. 43, No.1 (2016) 
TABLE 3. Effect of bio-fertilization with yeast applied as foliar application spraying, soil drench methods and their interaction on yield and chemical constituents of fenugreek seeds.

\begin{tabular}{|c|c|c|c|c|c|c|c|c|c|c|}
\hline \multirow{3}{*}{$\begin{array}{l}\text { Spraying } \\
\text { Drenching }\end{array}$} & \multicolumn{5}{|c|}{$1^{\text {st }}$ season $(2013 \backslash 2014)$} & \multicolumn{5}{|c|}{$2^{\text {nd }}$ season (2014|2015) } \\
\hline & \multicolumn{10}{|c|}{ Pods number plant $^{-1}$} \\
\hline & $0 \mathrm{~g} / \mathrm{L}$ & $5 \mathrm{~g} / \mathrm{L}$ & $10 \mathrm{~g} / \mathrm{L}$ & $15 \mathrm{~g} / \mathrm{L}$ & Mean & $\mathbf{0 g} / \mathrm{L}$ & $5 \mathrm{~g} / \mathrm{L}$ & $10 \mathrm{~g} / \mathrm{L}$ & $15 \mathrm{~g} / \mathrm{L}$ & Mean \\
\hline $0 \mathrm{~g} / \mathrm{L}$ & 3.60 & 5.73 & 10.70 & 6.71 & 6.69 & 6.31 & 13.97 & 7.30 & 10.31 & 9.47 \\
\hline $5 \mathrm{~g} / \mathrm{L}$ & 6.35 & 10.69 & 7.35 & 8.36 & 8.19 & 9.07 & 6.93 & 11.96 & 9.95 & 9.48 \\
\hline $10 \mathrm{~g} / \mathrm{L}$ & 8.75 & 5.79 & 7.25 & 15.31 & 9.28 & 11.90 & 6.87 & 9.41 & 17.36 & 11.39 \\
\hline $15 \mathrm{~g} / \mathrm{L}$ & 7.78 & 7.96 & 8.00 & 23.33 & 11.77 & 8.89 & 10.70 & 10.66 & 23.33 & 13.40 \\
\hline Mean & 6.62 & 7.54 & 8.33 & 13.43 & & 9.04 & 9.62 & 9.83 & 15.24 & \\
\hline L.S.D 5\% & \multicolumn{2}{|c|}{ (a) $=1.00$} & \multicolumn{3}{|c|}{$(\mathrm{b})=1.00 \quad(\mathrm{axb})=1.90$} & \multicolumn{3}{|c|}{$(a)=1.30 \quad(b)=1.30$} & \multicolumn{2}{|c|}{$(\mathrm{axb})=2.70$} \\
\hline \multicolumn{11}{|c|}{ Seeds weight plant $^{-1}(\mathrm{~g})$} \\
\hline $\mathbf{0 g} / \mathrm{L}$ & 2.05 & 2.41 & 2.96 & 4.23 & 2.91 & 2.09 & 2.16 & 2.90 & 4.29 & 2.86 \\
\hline $5 \mathrm{~g} / \mathrm{L}$ & 2.53 & 2.36 & 3.57 & 4.23 & 3.17 & 2.38 & 2.35 & 3.76 & 3.93 & 3.11 \\
\hline $10 \mathrm{~g} / \mathrm{L}$ & 2.55 & 2.62 & 3.81 & 4.27 & 3.31 & 2.71 & 2.49 & 3.94 & 4.50 & 3.41 \\
\hline $15 \mathrm{~g} / \mathrm{L}$ & 2.37 & 3.03 & 3.69 & 3.90 & 3.25 & 2.18 & 2.94 & 3.38 & 4.04 & 3.14 \\
\hline Mean & 2.38 & 2.61 & 3.51 & 4.16 & & 2.34 & 2.49 & 3.50 & 4.19 & \\
\hline L.S.D 5\% & \multicolumn{2}{|c|}{ (a) $=0.20$} & (b) $=0.20$ & \multicolumn{2}{|c|}{$(\mathrm{axb})=0.41$} & \multicolumn{3}{|c|}{ (a) $=0.24 \quad(b)=0.24$} & \multicolumn{2}{|c|}{$(\mathrm{axb})=0.48$} \\
\hline \multicolumn{11}{|c|}{$\begin{array}{l}\text { Seeds yield feddan } \\
-1 \\
\end{array}$} \\
\hline $\mathbf{0 g} / \mathrm{L}$ & 765.89 & 900.17 & 1102.84 & 1577.79 & 1086.67 & 778.33 & 805.68 & 1080.46 & 1601.41 & 1066.47 \\
\hline $5 \mathrm{~g} / \mathrm{L}$ & 942.45 & 879.04 & 1330.37 & 1579.03 & 1182.72 & 886.50 & 877.79 & 1401.24 & 1464.65 & 1157.55 \\
\hline $10 \mathrm{~g} / \mathrm{L}$ & 951.15 & 977.26 & 1422.37 & 1591.47 & 1235.56 & 1010.83 & 928.77 & 1470.86 & 1678.50 & 1272.24 \\
\hline $15 \mathrm{~g} / \mathrm{L}$ & 882.77 & 1128.95 & 1377.61 & 1454.70 & 1211.01 & 814.38 & 1097.86 & 1259.50 & 1508.16 & 1169.98 \\
\hline Mean & 885.57 & 971.36 & 1308.30 & 1550.75 & & 872.51 & 927.53 & 1303.02 & 1563.18 & \\
\hline L.S.D 5\% & \multicolumn{2}{|c|}{ (a) $=76.00$} & b) $=76.00$ & $(a x b)=1$ & 151.00 & (a) $=90.0$ & $0 \quad(\mathrm{~b}$ & $=90.00$ & $(\mathrm{axb})$ & $=180.00$ \\
\hline \multicolumn{11}{|c|}{ Content of seed mucilage $(\%)$} \\
\hline $0 \mathrm{~g} / \mathrm{L}$ & 16.40 & 23.77 & 22.26 & 17.66 & 20.02 & 16.31 & 19.00 & 21.52 & 16.96 & 18.45 \\
\hline $5 \mathrm{~g} / \mathrm{L}$ & 16.75 & 23.52 & 23.60 & 24.70 & 22.14 & 16.92 & 23.39 & 22.56 & 23.31 & 21.55 \\
\hline $10 \mathrm{~g} / \mathrm{L}$ & 23.15 & 17.00 & 23.46 & 24.73 & 22.09 & 22.48 & 16.59 & 22.60 & 24.18 & 21.46 \\
\hline $15 \mathrm{~g} / \mathrm{L}$ & 24.10 & 20.30 & 22.30 & 25.67 & 23.09 & 23.00 & 19.60 & 21.34 & 25.40 & 22.34 \\
\hline Mean & 20.10 & 21.15 & 22.91 & 23.19 & & 19.68 & 19.65 & 22.01 & 22.46 & \\
\hline \multicolumn{11}{|c|}{ Content of seed trigonelline $\left(\mathrm{mg} \cdot \mathrm{g}^{-1} \mathrm{DW}\right)$} \\
\hline $\mathbf{0 g} / \mathrm{L}$ & 14.39 & 22.76 & 20.25 & 15.65 & 18.27 & 14.80 & 17.49 & 20.01 & 15.45 & 16.94 \\
\hline $5 \mathrm{~g} / \mathrm{L}$ & 14.74 & 21.51 & 21.59 & 23.69 & 20.39 & 15.41 & 22.88 & 23.05 & 22.80 & 21.04 \\
\hline $10 \mathrm{~g} / \mathrm{L}$ & 23.14 & 14.99 & 23.45 & 22.72 & 21.08 & 20.97 & 15.08 & 21.09 & 23.67 & 20.21 \\
\hline $15 \mathrm{~g} / \mathrm{L}$ & 22.09 & 18.29 & 20.29 & 25.66 & 21.59 & 21.49 & 18.09 & 19.83 & 24.89 & 21.08 \\
\hline Mean & 18.59 & 19.39 & 21.40 & 21.93 & & 18.17 & 18.39 & 21.00 & 21.71 & \\
\hline \multicolumn{11}{|c|}{ Content of seed protein $\left({\left.\mathrm{g} . \mathrm{g}^{-1} \mathrm{DW}\right)}\right.$} \\
\hline $0 \mathrm{~g} / \mathrm{L}$ & 0.25 & 0.26 & 0.28 & 0.29 & 0.27 & 0.25 & 0.26 & 0.28 & 0.29 & 0.27 \\
\hline $5 \mathrm{~g} / \mathrm{L}$ & 0.26 & 0.29 & 0.30 & 0.31 & 0.29 & 0.26 & 0.30 & 0.30 & 0.30 & 0.29 \\
\hline $10 \mathrm{~g} / \mathrm{L}$ & 0.27 & 0.28 & 0.29 & 0.31 & 0.28 & 0.26 & 0.30 & 0.29 & 0.30 & 0.29 \\
\hline $15 \mathrm{~g} / \mathrm{L}$ & 0.28 & 0.30 & 0.31 & 0.32 & 0.30 & 0.29 & 0.28 & 0.30 & 0.31 & 0.30 \\
\hline Mean & 0.26 & 0.28 & 0.29 & 0.30 & & 0.27 & 0.29 & 0.29 & 0.30 & \\
\hline
\end{tabular}

Egypt. J. Hort. Vol. 43, No.1 (2016) 


\section{Chemical analysis of fenugreek plants}

Effect of bio-fertilization with yeast applied as foliar application spraying

Presented data in Table 4 clarifies that treating the plants with $10 \mathrm{~g} / \mathrm{l}$ of active dry yeast resulted in the highest values of chlorophyll $\mathrm{a}, \mathrm{b}$ and carotenoids contents in the fresh leaves mg. $\mathrm{g}^{-1}$ while the highest significant records of total carbohydrates content of dry leaves were obtained due to using the highest concentration $(15 \mathrm{~g} / \mathrm{l})$ in both seasons. It was noticed that using the moderate concentration $(10 \mathrm{~g} / \mathrm{l})$ gave, to an extent, approximate results to these of the highest concentration.

Such increase in photosynthetic pigments formation could be attributed to the role of yeast cytokinins which delaying the aging of leaves by reducing the degradation of chlorophyll and enhancing the protein and RNA synthesis (Castelfranco and Beale, 1983). These results were in agreement with (Costa et al., 2008) on Ocimum selloi, (Abdou et al., 2011) on clove Basil plant, (Abdou et al., 2012) on Fennel plants, (Hussain, 2002) on Majorana hortensis, (Abd ElLatif, 2006) on Salvia officinalis, (Naguib, 2002) on Cymbopogon flexuosus, (Seleim, 2005) on Mentha viridis and Salvia officinalis and (Ahmed and AbdelWahid, 2007) using active dry yeast at $6 \mathrm{~g} / \mathrm{l}$ increased the photosynthetic pigments in leaves and total carbohydrates percentage in the herb of Calendula officinals.

\section{Effect of bio-fertilization with yeast applied as soil drench}

The highest significant records of chlorophyll a, b, carotenoids' contents and total carbohydrates content in both seasons were produced from using the $15 \mathrm{~g} / \mathrm{l}$ of active dry yeast in both seasons as declared in Table 4 . These results are confirmed by authors like (Salman 2004) on Ocimum basilicum.

Effect of the interaction between application spraying and soil drench

Chemical constituents of Fenugreek plants, chlorophyll a, b, carotenoids contents and total carbohydrates content were significantly affected and highly increased by the interaction between yeast plants' spraying at $(10 \mathrm{~g} / \mathrm{l})$ along with soil drenching with yeast at $(15 \mathrm{~g} / \mathrm{l})$ except for total carbohydrates content which showed great reaction to the application of $15 \mathrm{~g} / \mathrm{l}$ in both spraying plus soil drenching in both seasons, as noticed in Table 4 .

\section{Conclusion}

To end up with, all treatments, spraying or drenching or both together, led to a highly significant increase in all studied characters, namely, vegetative growth, yield and chemical constituents of Fenugreek plants. Among all concentrations of active dry yeast, the highest ones (10 and $15 \mathrm{~g} / \mathrm{l})$ used individually as spraying or drenching, were of more benefit than the control in recording the highest values of vegetative growth characters, seed yield and chemical constituents. All interaction treatments, spraying the plants with $15 \mathrm{~g} / \mathrm{l}$ along with drenching the soil with 15 or $10 \mathrm{~g} / \mathrm{l}$ of active dry yeast was of the most significant values in all vegetative 
growth attributes and seed yield and its chemical constituents, mucilage (\%) trigonelline and protein content. Spraying the plants with $10 \mathrm{~g} / \mathrm{l}$ plus drenching the soil with $15 \mathrm{~g} / \mathrm{l}$ was the most effective treatment for obtaining the highest values of the chemical constituents of Fenugreek plants, chlorophyll a, b, carotenoids contents while highest total carbohydrates content was given from spraying with drenching at $15 \mathrm{~g} / \mathrm{l}$ for both treatments. Hence, it can be concluded that Fenugreek plants responded greatly to foliar spraying with active dry yeast than soil drenching but the interaction of both treatments was the most effective than using each one individually. Generally speaking, there was a gradual increase in all vegetative growth, yield and chemical characters as increasing the concentration of active dry yeast $(5,10$ and $15 \mathrm{~g} / \mathrm{l})$.

TABLE 4. Effect of bio-fertilization with yeast applied as foliar application spraying, soil drench methods and their interaction on chemical composition of fenugreek plants .

\begin{tabular}{|c|c|c|c|c|c|c|c|c|c|c|}
\hline \multirow{3}{*}{ Drenching } & \multicolumn{5}{|c|}{$1^{\text {st }} \operatorname{season}(2013 \backslash 2014)$} & \multicolumn{5}{|c|}{$2^{\text {nd }} \operatorname{season}(2014 \backslash 2015)$} \\
\hline & \multicolumn{10}{|c|}{ Chlorophyll A $\left(\mathrm{mg} \mathrm{g}^{-1}\right)$} \\
\hline & $0 \mathrm{~g} / \mathrm{L}$ & $5 \mathrm{~g} / \mathrm{L}$ & $10 \mathrm{~g} / \mathrm{L}$ & $15 \mathrm{~g} / \mathrm{L}$ & Mean & $0 \mathrm{~g} / \mathrm{L}$ & $5 \mathrm{~g} / \mathrm{L}$ & $10 \mathrm{~g} / \mathrm{L}$ & $15 \mathrm{~g} / \mathrm{L}$ & Mean \\
\hline $0 \mathrm{~g} / \mathrm{L}$ & 0.89 & 1.27 & 1.29 & 1.66 & 1.28 & 0.93 & 1.31 & 1.45 & 1.70 & 1.35 \\
\hline $5 \mathrm{~g} / \mathrm{L}$ & 0.90 & 1.14 & 1.64 & 1.70 & 1.35 & 0.93 & 1.19 & 1.67 & 1.75 & 1.39 \\
\hline $10 \mathrm{~g} / \mathrm{L}$ & 1.43 & 1.44 & 1.62 & 1.25 & 1.44 & 1.47 & 1.47 & 1.58 & 1.44 & 1.49 \\
\hline $15 \mathrm{~g} / \mathrm{L}$ & 1.39 & 1.30 & 1.81 & 1.57 & 1.52 & 1.42 & 1.31 & 1.80 & 1.61 & 1.54 \\
\hline Mean & 1.15 & 1.29 & 1.59 & 1.55 & & 1.19 & 1.32 & 1.63 & 1.63 & \\
\hline L.S.D 5\% & \multicolumn{2}{|c|}{ (a) $=0.02$} & (b) $=0.02$ & \multicolumn{2}{|c|}{$(\mathrm{axb})=0.05$} & \multicolumn{3}{|c|}{ (a) $=0.19$} & \multicolumn{2}{|c|}{$(\mathrm{axb})=0.38$} \\
\hline \multicolumn{11}{|c|}{ Chlorophyll B $\left(\mathrm{mg} \mathrm{g}^{-1}\right)$} \\
\hline $0 \mathrm{~g} / \mathrm{L}$ & 0.64 & 0.98 & 0.89 & 1.29 & 0.95 & 0.67 & 0.98 & 1.04 & 0.91 & 0.90 \\
\hline $5 \mathrm{~g} / \mathrm{L}$ & 0.64 & 0.78 & 1.30 & 1.04 & 0.94 & 0.77 & 0.91 & 1.04 & 1.30 & 1.01 \\
\hline $10 \mathrm{~g} / \mathrm{L}$ & 0.76 & 1.09 & 1.03 & 1.09 & 0.99 & 0.85 & 1.06 & 1.06 & 0.96 & 0.98 \\
\hline $15 \mathrm{~g} / \mathrm{L}$ & 0.94 & 0.96 & 1.34 & 1.05 & 1.07 & 0.95 & 0.95 & 1.31 & 1.08 & 1.07 \\
\hline Mean & 0.75 & 0.95 & 1.14 & 1.12 & & 0.81 & 0.98 & 1.11 & 1.06 & \\
\hline L.S.D 5\% & \multicolumn{2}{|c|}{ (a) $=0.04$} & (b) $=0.04$ & \multicolumn{2}{|c|}{$(\mathrm{axb})=0.09$} & \multicolumn{2}{|c|}{ (a) $=0.13$} & $0)=0.13$ & \multicolumn{2}{|c|}{$(\mathrm{axb})=0.25$} \\
\hline \multicolumn{11}{|c|}{ Carotenoids (mg g $\left.{ }^{-1}\right)$} \\
\hline $0 \mathrm{~g} / \mathrm{L}$ & 0.36 & 0.44 & 0.46 & 0.56 & 0.46 & 0.37 & 0.43 & 0.44 & 0.52 & 0.44 \\
\hline $5 \mathrm{~g} / \mathrm{L}$ & 0.45 & 0.45 & 0.57 & 0.47 & 0.49 & 0.42 & 0.50 & 0.46 & 0.45 & 0.46 \\
\hline $10 \mathrm{~g} / \mathrm{L}$ & 0.48 & 0.45 & 0.65 & 0.54 & 0.53 & 0.40 & 0.42 & 0.58 & 0.48 & 0.47 \\
\hline $15 \mathrm{~g} / \mathrm{L}$ & 0.56 & 0.54 & 0.67 & 0.56 & 0.58 & 0.34 & 0.47 & 0.74 & 0.46 & 0.50 \\
\hline Mean & 0.46 & 0.47 & 0.59 & 0.53 & & 0.38 & 0.46 & 0.56 & 0.48 & \\
\hline L.S.D 5\% & \multicolumn{2}{|c|}{ (a) $=0.03$} & (b) $=0.0$ & \multicolumn{2}{|c|}{$(\mathrm{axb})=0.05$} & \multicolumn{3}{|c|}{$(a)=0.07 \quad(b)=0.07$} & \multicolumn{2}{|c|}{$(\mathrm{axb})=0.14$} \\
\hline \multicolumn{11}{|c|}{ Total Carbohydrates content of leaves (\%) } \\
\hline $0 \mathrm{~g} / \mathrm{L}$ & 24.92 & 26.62 & 22.06 & 30.80 & 26.10 & 22.44 & 24.45 & 20.11 & 25.79 & 23.20 \\
\hline $5 \mathrm{~g} / \mathrm{L}$ & 26.64 & 24.25 & 28.32 & 29.53 & 27.19 & 21.46 & 23.11 & 25.70 & 27.45 & 24.43 \\
\hline $10 \mathrm{~g} / \mathrm{L}$ & 27.55 & 26.62 & 26.16 & 29.33 & 27.42 & 24.08 & 23.71 & 22.80 & 26.41 & 24.25 \\
\hline $15 \mathrm{~g} / \mathrm{L}$ & 26.23 & 30.32 & 25.31 & 30.88 & 28.19 & 27.65 & 24.44 & 24.15 & 29.14 & 26.35 \\
\hline Mean & 26.34 & 26.95 & 25.46 & 30.14 & & 23.91 & 23.93 & 23.19 & 27.20 & \\
\hline L.S.D 5\% & \multicolumn{2}{|c|}{$(a)=1.90$} & $(b)=1.9 x$ & \multicolumn{2}{|c|}{$(\mathrm{axb})=3.81$} & \multicolumn{3}{|c|}{ (a) $=2.10 \quad(b)=2.10$} & \multicolumn{2}{|c|}{$(\mathrm{axb})=4.20$} \\
\hline
\end{tabular}

Egypt. J. Hort. Vol. 43, No.1 (2016) 


\section{References}

Abd El-Azim, M.W. A. and Abd El-Gawad, A.M.A. (2008) Effect of treatment with tryptophan and yeast on soil microbial activities, growth and productivity of Thymus vulgaris, L. under middle Sinai conditions. Annals of Agricultural Sci., 53 (1), 105-116.

Abd El-Latif, E.S. (2006) Effect of chemical, organic and spraying with active dry yeast on growth, oil production and plant constituents of sage (Salvia officinalis L.) plants. M.Sc. Thesis, Fac. Agric., Cairo Univ., Egypt.

Abdou, M.A.H., Abdalla, M.Y.A., Hegazy, A. A. and Marzok, Z.S.A. (2011) Physiological studies on clove basil plant. J. Plant Production, Mansoura Univ., 2 (11), 1451-1469.

Abdou, M.A.H., Taha, R. A., Abd-Elraaof, R.M. and Salah El-Deen, R.M. (2012) Response of Fennel plants to organic, bio and mineral fertilization. Egypt j. Bot. 2nd Inter. conference, 29-30 April, Minia Univ., pp. 191-205.

Abou-Dahab, A.M., Mansour, H.A., Hashim, M.F. and Abd-El-Wahab, A.T. (2009) Effect of radiation and chicken manure on growth of lovage plant (Levisticum officinale Koch.). $4^{\text {th }}$ Conference on Recent Technologies in Agriculture.

Ahmed, A.A. (2002) Study on the effect of addition methods and concentrations of active dry yeast on the growth and chemical composition of Leucaena leucocephala. Minia 1st Conf. for Agric. \& Environ. Sci., Minia Univ. Egypt, 25-28 March, 367-376.

Ahmed, F.F., Gobara, A.A., Ragab, M.A. and Mansour, A.E.M. (1997) Improving the efficiency of spraying different nutrient for red roomy grape vines (Vitis vinifera L .) by using glycerol and active dry yeast. Egypt. J. Hort., 24 (1), 91-108.

Ahmed, G.E.F. and Abdel-Wahid, S.M.K. (2007) Production of Calendula officinalis L plants by using whey and active dry yeast as biofertilizers. Egyptian J. Appl., 22, 590-613.

Ahmed, S.K., Ali, A.F. and Khater, M.R. (2001) Effect of salinity treatments and active dry yeast on growth and active ingredients of Ambrosia maritima, L. Proc. Fifth Arabian Hort. Conf., Ismailia, Egypt, 25-28 March, 217-224.

Ahmed, S.K., El-Ghawas, E.O. and Aly, A.F. (1998) Effect of active dry yeast and organic manure on Roselle plant. Egypt. J. Agric. Res., 76 (3), 1115-1143.

Alves, E.U., Oliveira, A.P., Bruno, R.L.A., Sader, R. and Alves, A.U. (2005) Yield and physiological quality of coriander seeds cultivated with manure and mineral fertilizer. Revista Brasileira de Sementes. Associacao Brasileira de Tecnologia de Sementes (ABRATES), Brasilia, Brazil, 27 (1), 132-137.

Amer, S.S.A. (2004) Growth, green pods yield and seeds yield of common bean (Phaseolus vulgaris L.) as affected by active dry yeast, salicylic acid and their interaction. J. Agric Sci. Mansoura Univ., 29 (3), 1407-1422.

Armanious, R.R. (1987) Studies on interaction between microorganism related from Egyptian soil in relation to soil fertility. Ph. D Thesis, Fac. Agri. Cairo Univ. 
Arnon, D.I. (1949) Copper enzymes in isolated chloroplast. Poly phenol - oxidize in Beta vulgaris L. Plant Physiol., 24, (1), 1-15.

Betty, R. (2008) The many healing virtues of fenugreek. Spice India. 1, 17-19.

Carmen, C., Ledesma, A. and Del-Longo, O. (2006) Biofertilizers (vermicomposting) as sustainable alternative to urea application in the production of basil (Ocimum basilicum L.) Molecular Medicinal Chemistry, 11 (9-12), 28-30.

Castelfranco, P. A. and Beale, S. I. (1983) Chlorophyll biosynthesis recent advances and areas of current interest. Ann. Rev. Plant Physiol., 34, 241-278.

Chaliakhyan, M. K. (1957) Effect of Vitamins on growth and development of plants Dokly Akad. Nauk. SSSK, 111, 894-897.

Costa, L.C.B., Pinto, J.E.B., Castro, E.M., Bertolucci, S.K.V., Corrêa, R.M., Alves, P.B. and Niculau, E.S. (2008) Sources and doses of organic fertilization in Ocimum selloi growth, essential oil yield and chemical composition. Ciência Rural. 38(8), 2173-2180.

El-Naggar, A.H.M., Hassan, M.R.A., Shaban, E.H. and Mohamed, M.E.A. (2015) Effect of organic and biofertilizers on growth, fruit yield and chemical composition of the essential oil of Ocimum basillicum L. plants. Alex. J. Agric. Res., 60 (1), 1-16.

Ezz El-Din, A.A. and Hendawy, S.F. (2010) Effect of dry yeast and compost tea on growth and oil content of Borago officinalis plant. Res. J. Agric. Biological Sci., 6 (4), 424-430.

Gomez, K.A. and Gomez, A. A. (1983) "Statistical Analysis", Procedures of Agric. Res. Joh Wiley and Sons, New York.

Haridi, S.M.M. (1987) Biochemical studies on sage Salvia officinalis plants. Ph.D. Thesis., Fac. Agric. Ain Shams Univ.

Heikal, Amaal A.M. (2005) Effect of organic and bio-fertilization on growth, production and composition of Thymus vulgaris, L. plants. M.Sc. Thesis, Fac. Agric., Cairo Univ., Egypt.

Herbert, D., Phipps, P.J. and Strange, R.E. (1971) Determination of Total Carbohydrates. "Methods in Microbiology", 5 p. Academic Press, London, 290-344.

Hussain, M.A. (2002) Effect of some agriculture treatments on growth and chemical composition of Majorana hortensis plants. M.Sc. Thesis., Fac. Agric., Minia Univ.

Im, K.K. and Maliakel, B.P. (2008) Fenugreek dietary fibre a novel class of functional food ingredient. Agro Food Industry Hi-Tech., 19(2), 18-21.

Jacoub, R.W. (1999) Effect of some organic and non-organic fertilizers on growth, oil yield and chemical composition of Ocimum basilicum, L. and Thymus vulgaris, L. plants. Ph. D. Thesis, Fac. Agric., Cairo Univ., Egypt.

Egypt. J. Hort. Vol. 43, No.1 (2016) 
Jani, R., Udipi, S. and Ghugre, P. (2009) Mineral content of complementary foods. The Indian Journal of Pediatrics, 76(1), 37- 44.

Khaled, S.A., Abdella, E.M. and Mohamcd, C.F. (2014) Response of growth, chemical composition, anatomical structure, antioxidant and antimicrobial activity of Marjoram to yeast and methionine. Inter. J. Academic Res., 6 (1), 18-30.

Khedr, Z. M. and Farid, S. (2000) Response of naturally virus infected-tomato plants to yeast extract and phosphoric acid application. Ann. Sci. Moshtohor, Egypt, 38, 927-939.

Klute, A. (1986) "Methods of Soil Analysis", Part 1, Physical and Mineralogical Methods $2^{\text {nd }}$ ed., Amer. Soc. Agron. Madison, Wisconsin, USA.

Kurtzman, C.P. and Fell, J.W. (2005) Biodiversity and Ecophysiology of Yeasts, In: "The Yeast Handbook", Gabor P, de la Rosa CL, (Ed.) Berlin, Springer, 11-30.

Mady, A. (2009) Effect of certain medicinal plant extracts on growth, yield and metabolism of some medicinal aromatic and plants. M.Sc. Thesis, Botany and Microbiology Dept., Fac. Sci., Al-Azher Univ.

Moghadam, A.R.L., Ardebili, Z.O. and Saidi, F. (2012) Vermicompost induced changes in growth and development of Lilium Asiatic hybrid var. Navona. African J. Agric. Res., 7 (17), 2609-2621.

Mohamed, F.I., Helal, F.A. and El-Shabrawy, R.A. (1999) A comparative study on the effect of bread yeast and foliar nutrients application on the productivity and quality of two Pea cultivars. Egypt. J. Applied Sci., 14(10), 284-289.

Moor, T.C. (1979) Biochemistry and Physiology Plant Hormones. Springer Verlage, New York, U.S.A., 176 p.

Muller, K. and Leopold, A.C. (1966) Mechanism of kinetin induced transport in corn leaves. Planta, 68, 185- 205.

N.R.P. (1977) Nutrient Requirements of Domestic-Animals, No 1,7th rev. edition. National Academy Sci. Washington, D.C., 173 p.

Naga, N.M.H. (2004) Physiological studies on (Foeniculum vulgare Mill) and (Carum carvi L.). M.Sc. Thesis, Fac. Agric., Tanta, Univ.

Nagodawithana, W.T. (1991) Yeast technology. Universal foods corporation Milwaukee, Wisconsim, published by Van Nostrand Reinhold, New York, p.273. 
Naguib, Nabila Y. (2002) Yield and quality of lemon (Cymhopogon flexuosus, Stapf) as influenced by farmyard manure and foliar application of bread yeast. Annals Agric. Sci. Ain Shams Univ., 47 (3), 859-873.

Page, A.I., Miler, R.H. and Keeny, D.R. (1982) "Methods of Soil Analysis" part II. Chemical and Microbiological Methods. $2^{\text {nd }}$ ed. Amer. Soc. Agron., Madison, Wisconsin, USA.

Sabale, V., Patel, V., Paranjape, A. and Sabale, P. (2009) Isolation of fenugreek seed mucilage and its comparative evaluation as a binding agent with standard binder. Inter. J. Pharmaceutical Res., 1 (4), 56-62.

Salman, A.S. (2004) Effect of biofertilization on Ocimum baslicum, L. plant. M.Sc. Thesis, Fac. Agric., Cairo Univ., Egypt, 136 p.

Seleim, Maida, K.M. (2005) Physiological studied on some medicinal plants. M.Sci. Thesis, Fac. Agri. Tanta Univ., Egypt.

Shalaby, M.E. and El-Nady, M.F. (2008) Application of Saccharomyces cerevisiae as a biocontrol agent against Fusarium infection of sugar beet plants. Acta Biologica Szegediensis, 52 (2), 271-275.

Trivedi, P.D., Pundarikakshudu, K., Rathnam, S. and Shah, K.S. (2007) A validated quantitative thin-layer chromatographic method for estimation of diosgenin in various plant samples, extract, and market formulation. J. AOAC Inter., 90 (2), 358-63.

Warring, P.E. and Phillips, L.D.G. (1973) The control of growth and differentiation in plants. E.L.B.S. ed Pergamon Press Ltd. UK., 303.

Zheng, X.Q. and Ashihara, H. (2004) Distribution, biosynthesis and function of purine and pyridine alkaloids in Coffea arabica seedlings. Plant Sci., 166, 807-813.

(Received 10/1/2016 accepted $7 / 4 / 2016)$

Egypt. J. Hort. Vol. 43, No.1 (2016) 
تأثير طرق التسميد الحيوى على النمو الخضري ومحصول البذور والمكونات

الكميائية لتبات الحلبة التبرة

فيصل محمود عبدالمجيد مطر و علاء إلبات إدريس بلدوى أبو سريع

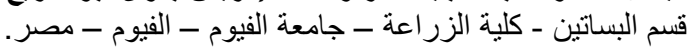

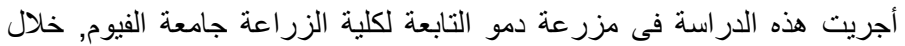

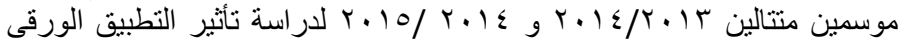

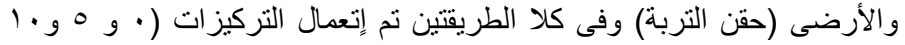

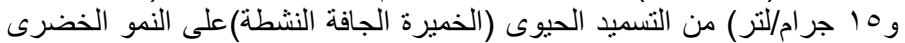

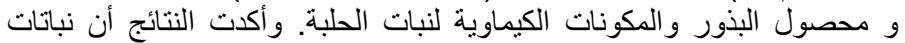

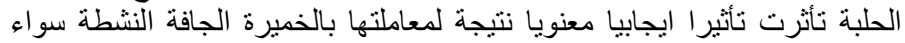

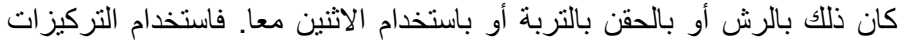

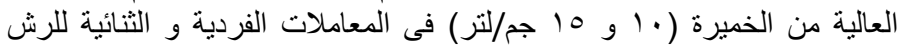

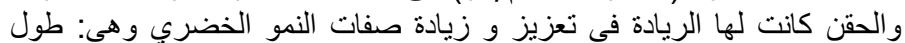

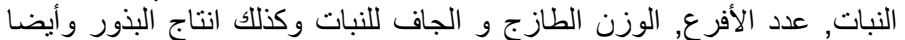

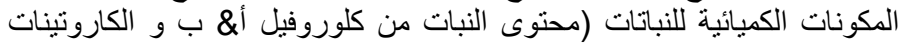

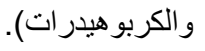

و لهذا يمكن التوصية برش نباتات الحلبة أو بحقن التربة بتركيز ـ الو أو 10

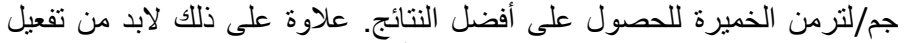

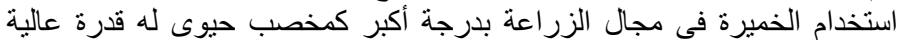
على زيادة محصول البذور ومكون فاتها الكمياوية. 